\title{
PENGARUH PERHATIAN ORANG TUA TERHADAP PRESTASI BELAJAR
}

\author{
Ardiansyah $^{1)}$ Abdulrahim Maruwae ${ }^{2)}$ \\ Universitas Negeri Gorontalo \\ e-mail: ardiansyah@ung.ac.id
}

\begin{abstract}
ABSTRAK
Tujuan penelitian ini adalah untuk mengatahui pengaruh perhatian orang tua terhadap Prestasi Belajar peserta didik pada mata pelajaran ekonomi di kelas XI IPS SMA Negeri 1 Bontomatene Kabupaten Kepulauan Selayar. Populasi dalam penelitian ini adalah seluruh peserta didik kelas XI IPS SMA Negeri 1 Bontomatene Kabupaten Kepulauan Selayar. Penarikan sampel dalam penelitian ini menggunakan teknik sampling jenuh. Ada dua jenis variabel yang digunakan dalam penelitian ini yaitu variabel bebas (independen) dan variabel terikat (dependen). Adapun variabel bebas dalam penelitian ini adalah perhatian orang tua sedangkan variabel terikat yaitu prestasi belajar peserta didik pada mata pelajaran. Teknik analisi data yang digunakan adalah uji analisis regresi sederhana Hasil penelitian ini menunjukkan bahwa perhatian orang berpengaruh positif dan signifikan terhadap Prestasi Belajar .
\end{abstract}

Kata Kunci:, Perhatian Orang Tua, Prestasi Belajar

\begin{abstract}
ABTRACT
The research aims to discover the influence of parents' attentions have influence on students' learning achievements in Economy subject in class XI IPS at SMAN 1 Bontomatene in Kepulauan Selayar District. The population in this study were all students of class XI IPS SMA Negeri 1 Bontomatene Selayar Islands Regency. Sampling in this study using a saturated sampling technique There are two types of variables used in this study, namely the independent variable and the dependent variable.The independent variable in this study is the attention of parents while the dependent variable is student achievement in subjects The data analysis technique used is a simple regression The results of the research reveal that the parents' attentions have positive and significant influence partially on students' learning achievements in Economy subject in class XI IPS at SMAN 1 Bontomatene in Kepulauan Selayar District.
\end{abstract}

Key Words:, Parents' Attention, The Learning Achievements 


\section{PENDAHULUAN}

Perhatian pada dasarnya bisa dari kesadaran dan juga bagaimana cara timbulnya. Perhatian yang menjadi fokus dalam penelitian ini adalah perhatian orangtua. Perhatian orang tua terhadap anak sangat penting karena keluarga adalah lembaga pendidika nonformal yang bertangungjawab terhadap pendidikan anak. Manusia pada umumnya bertindak karena didorong oleh pengaruh- pengaruh yang timbul dari dirinya, semua kebutuhan itu bermacam-macam ada yang berupa kebutuhan yang berhubungan dengan jasmani,psikologis dan sosial. Menurut Walgito (1994:13) "kebutuhan pada umumnya adalah (1) kebutuhan yang bersifat fisiologis,(2) kebutuhan yang bersifat psikologis,(3) kebutuhan yang bersifat sosial,(4) kebutuhan yang bersifat religi". Selanjutnya dimaksud orang tua dalam penlitian ini adalah ayah dan ibu kandung peserta didik.

Terkait dengan dunia pendidikan, untuk menciptakan manusia yang berkualitas dan berprestasi tinggi maka peserta didik harus memiliki prestasi belajar yang baik. Presasi belajar merupakan tolak ukur maksimal yang telah dicapai peserta didik dalam melakukan perbuatan belajar selama waktu yang telah ditentukan bersama. Dalam suatu lembaga pendidikan, prestasi belajar merupakan indikator yang penting untuk mengukur keberhasilan proses belajar mengajar. Tinggi rendahnya prestasi peserta didik banyak dipengaruhi oleh faktor- faktor lain disamping proses pengajaran itu sendiri.(Jansen, van Leeuwen, Janssen, Jak, \& Kester, 2019)(Partovi \& Razavi, 2019).

Faktor yang mempengaruhi prestasi belajar antar peserta didik berbedabeda, ini menimbulkan prestasi yang dicapai masing-masing individu tidak sama. Banyak faktor yang memepengaruhi keberhasilan belajar peserta didik yaitu faktor ekstern dan faktor intern. Faktor ekstern adalah faktor yang berasal dari luar individu yang meliputi lingkungan keluarga, sekolah dan masyarakat. Sedangkan faktor intern adalah faktor yang ada dalam diri individu yang meliputi faktor jasmaniah, psikologis, kelelahan.(Prasertcharoensuk, Somprach, \& Ngang, 2015).

Banyak faktor yang mempengaruhi tingkat pendidikan anak (gunawan, 2002). Salah satu faktor yang berasal dari luar diri peserta didik (ekstern) adalah lingkungan keluarga khusunya perhatian orang tua. Hal-hal yang perlu mendapat perhatian orang tua adalah pemenuhan kebutuhan yaitu terhadap kebutuhan fisik, psikologis, kebutuhan religi dan kebutuhan sosialnya. Dengan memperhatikan kebutuhan-kebutuhan anak tersebut, orang tua akan lebih mudah memberikan rangsangan-rangsangan terhadap cara berfikir anak. (Park, Pan, \& Ahn, 2020).

Perhatian yang maksimal timbul karena adanya dorongan, keinginan dan pengalaman pribadi orang tua. Untuk itu perlu perhatian yang besar, baik dalam hal 
belajar anaknya di rumah maupun di sekolah. Kondisi orang tua berpengaruh terhadap semangat belajar anak (Ahmad Susanto,2016).

Perhatian orang tua juga mempunyai peranan yang sangat berpengaruh terhadap siswa. Anak didik bersosialisasi pertama kali terjadi dilingkungan keluarga. Apabila proses sosialisasi itu berlangsung dengan baik, maka seorang anak akan tumbuh dengan perilaku yang baik pula di masyarakat, sedangkan sebaliknya maka tidak jarang anak akan berperilaku buruk. Orang tua mempunyai tugas di dalam membentuk kepribadian pada anak, apabila sikap orang tua yang memberikan perhatian lebih dan perlakuan istimewa pada siswa maka akan memicu adanya sifat perilaku konsumsi akan meningkat.(Wulandari, Wahyono, \& Haryono, 2016). Sikap dan cara pergaulan di dalam keluarga memegang peranan yang penting dalam pendidikan anak.(Akindinova, Kuzminov, \& Yasin, 2016).

Menurut pengamatan di SMA Negeri 1 Bontomatene Kabupaten Kepulauan Selayar tingkat prestasi belajar peserta didiknya masih kurang optimal, khususnya mata pelajaran ekonomi pada kelas XI IPS yang masih di bawah standar kriteria ketuntasan minimal (KKM). Hal ini dipengaruhi dari salah satu factor eksternal berupa kurangnya perhatian orang tua yang terhadap perkembangan pendidikan anak.

Dari fenomena yang ditemukan lapangan mengidentifikasikan adanya dugaan yang cukup kuat hubungan dan pengaruh faktor ekstern peserta didik yang berupa perhatian orang tua terhadap prestasi belajar. Oleh karena itu peneliti berminat untuk mengkaji lebih lanjut mengenai pentingnya perhatian orang tua dalam pencapaian prestasi belajar peserta didik

\section{METODE PENELITIAN}

Penelitian ini menggunakan penelitian kuantitatif yakni mengukur Pengaruh perhatian orang tua terhadap prestasi belajar peserta didik pada mata pelajaran ekonomi di kelas XI IPS SMA Negeri 1 Bontomatene Kabupaten Kepulauan Selayar. Ada dua jenis variabel yang digunakan dalam penelitian ini yaitu variabel bebas (independen) dan variabel terikat (dependen). Adapun variabel bebas dalam penelitian ini adalah perhatian orang tua Sedangkan variabel terikat yaitu prestasi belajar peserta didik mata pelajaran ekonomi SMA Negeri 1 Bontomatene Kabupaten Kepulauan Selayar berupa nilai rapor semester ganjil. Adapun teknik analisis data yang digunakan dalam penelitian ini adalah analisis regresi sederhana dengan taraf signifikan $0.05 \%$.

\section{HASIL PENILITIAN}

Penyajian data mengenai identitas responden untuk memberikan gambaran tentang keadaan diri dari responden. Deskripsi data yang akan disajikan dari hasil 
penelitian ini adalah untuk memberikan gambaran secara umum mengenai penyebaran data yang diperoleh di lapangan. Data yang disajikan berupa data mentah yang diperoleh menggunakan statistik deskripsi.

Populasi dalam penelitian ini adalah seluruh peserta didik kelas XI IPS SMA Negeri 1 Bontomatene Kabupaten Kepulauan Selayar Tahun Ajaran 2016/2017 yang berjumlah 76 peserta didik, Keselurahan peserta didik tersebut terbagi dalam tiga kelas yang ditampilkan dengan tabel sebagai berikut :

\section{Tabel 1.1}

\section{Populasi Penelitian Peserta didik Kelas XI Jurusan IPS SMA Negeri 1 Bontomatene}

\begin{tabular}{ccc}
\hline Nomor & Kelas & Jumlah peserta didik \\
\hline 1 & XI IPS 1 & 24 \\
2 & XI IPS 2 & 27 \\
3 & XI IPS 3 & 25 \\
\hline & Jumlah & 76 \\
\hline
\end{tabular}

Penarikan sampel dalam penelitian ini menggunakan teknik sampling jenuh. Menurut Sugiyono (2008:122) "Sampel jenuh adalah teknik penentuan sampel bila semua anggota populasi digunakan sebagai sampel." Penelitian ini menggunakan sampel jenuh yaitu keseluruhan jumlah populasi sebanyak 76 peserta didik.Jumlah responden yang diambil dalam penelitian ini adalah 76 responden. Deskripsi dari masing-masing variabel berdasarkan hasil penyebaran kuesioner kepada tiap-tiap responden dan hasilnya dapat dijelaskan berdasarkan jenis kelamin. Jenis kelamin secara umum dapat memberikan perbedaan pada perilaku seseorang. Dalam suatu bidang kerja. Jenis kelamin seringkali dapat menjadi pembeda aktivitas yang dilakukan oleh individu. Penyajian data responden berdasarkan jenis kelamin sebagai berikut: 
Tabel 1.2.

Karakteristik Responden Berdasarkan Jenis Kelamin

\begin{tabular}{ccccc}
\hline \multirow{2}{*}{ KELAS } & \multicolumn{2}{c}{ Jenis Kelamin } & $\begin{array}{c}\text { Jumlah Responden } \\
\text { (orang) }\end{array}$ & Persentase(\%) \\
\cline { 2 - 3 } & Laki-laki & Perempuan & 24 & 31 \\
\hline XI IPS 1 & 15 & 9 & 27 & 36 \\
XI IPS 2 & 17 & 10 & 25 & 33 \\
XI IPS 3 & 17 & 8 & 76 & 100 \\
\hline Total & 49 & 27 & & \\
\hline
\end{tabular}

Berdasarkan tabel 1.2 diketahui bahwa pada kelas XI IPS 1 jumlah responden sebanyak 24 orang atau $31 \%$ yang terdiri dari jenis kelamin laki-laki sebanayak 15 orang dan perempuan sebanyak 9 orang. Sehingga total responden pada kelas XI IPS 1 berjumlah 24 orang atau 31\%. Pada kelas XI IPS 2 jumlah responden sebanyak 27 orang atau $36 \%$ yang terdiri dari jenis kelamin laki-laki sebanyak 17 orang dan 10 orang perempuan. Responden pada kelas XI IPS 3 berjumlah 25 orang atau 33\% yang terdiri dari jenis kelamin laki-laki sebanyak 17 orang dan perempuan sebanyak 8 orang.

a. Uji Normalitas Data

Sebelum dilakukan analisis data lebih lanjut, terlebih dahulu perlu diketahui apakah data penelitian ini sudah memenuhi persyaratan statistik yang akan digunakan dalam menguji hipotesis. Pengujian persyaratan analisis untuk penggunaan statistik adalah yang diperoleh sekurang-kurangnya terdistribusi normal.

Uji normalitas data dimaksudkan untuk mengetahui kenormalan data tiap variabel. Kriteria dari pengujian ini adalah dengan menggunakan metode uji normalitas data Kolmogorof-Smirnov dan melihat Grafik normal P-P plot. Dasar pengambilan keputusan normal atau tidaknya data yang diolah dalam kolmogrovsmirnov adalah sebagai berikut :

1) Jika nilai signifikan yang dihasilkan $>0,05$ maka distribusi sampel normal.

2) Jika nilai signifikan yang dihasilkan $<0,05$ maka distribusi sampel tidak normal. 
Tabel 1.3. Distribusi normal data one-sample Kolmogorof-Smirnov Test

\begin{tabular}{ccc}
\hline \multicolumn{3}{c}{ On - Sample Kologmorov-Smirnov Test } \\
\hline Variabel & Kologmorov-Smirnov Z & Asymp. Sig. (2-tailed) \\
\hline Perhatian Orang Tua & 0,859 & 0.452 \\
Motivasi Belajar & 0,869 & 0,436 \\
Prestasi Belajar & 0,678 & 0,747 \\
\hline
\end{tabular}

Berdasarkan tabel 1.3 perhitungan diperoleh nilai Kolmogorov-Smirnov untuk variabel perhatian orang tua belajar sebesar 0,859 dengan probabilitas 0,452 lebih besar dari 0,05 sehingga dapat dinyatakan data untuk variabel perhatian orang tua belajar berdistribusi normal. Variabel motivasi belajar sebesar 0,869 dengan probabilitas sebesar 0,436 lebih besar dari 0,05 sehingga data untuk variabel motivasi belajar dinyatakan berdistribusi normal. Variabel prestasi belajar sebesar 0,678 dengan probabilitas sebesar 0,747 lebih besar dari 0,05 sehingga data untuk variabel prestasi belajar dinyatakan berdistribusi normal.

\section{b. Uji Multikolinieritas}

Uji multikolinieritas bertujuan untuk menguji apakah model regresi ditemukan adanya korelasi antar variabel bebas (independen). Ghozali (2006) berpendapat bahwa "Model regresi yang baik seharusnya tidak terjadi korelasi diantara variable bebas". Syarat berlakunya model regresi ganda adalah antar variabel bebasnya tidak memiliki hubungan sempurna atau tidak mengandung multikolinieritas. Pengujian multikolinieritas ini dapat dilihat dari variance inflation factor (VIF) dan nilai tolerance. Antara variabel bebas dikatakan multikolinieritas apabila toleransinya $>0,1$ dan VIF $<10$. Hasil pengujian multikolinieritas selengkapnya dapat dilihat pada table berikut ini :

Tabel 1.4.Uji multikolinieritas

\begin{tabular}{ccc}
\hline Variabel & Tolerance & VIF \\
\hline Perhatian Orang Tua & 0,927 & 1,079 \\
Motivasi Belajar & 0,927 & 1,079 \\
\hline
\end{tabular}

Terlihat dari Tabel 1.4 diperoleh nilai VIF untuk variabel perhatian orang tua belajar sebesar 1,079 dibawah 10 dan nilai toleransi 0,927 diatas 0,1 sehingga dapat disimpulkan bahwa model regresi tidak mengandung multikolinieritas. Variabel motivasi belajar sebesar 1,079 dibawah 10 dan nilai toleransi 0,927 
diatas 0,1 sehingga variabel inipun model regresinya juga tidak mengandung multikolinieritas.

\section{c. Uji Heterokedastisitas}

Untuk menguji apakah model regresi terjadi heteroskedastitas atau tidak, penelitian ini menggunakan dua cara yaitu dengan grafik Scatter Plot dan uji Glejser.Langkah ini digunakan untuk menguji apakah dalam model regresi memiliki perbedaan satu ke kasus pengamatan yang lain. Pengujian ini dapat dilihat dari grafik Multivariate Standardized Scatter Plot melalui program SPSS for Windows Release 21,00.

Uji heterokedastisitas dalam penelitian ini kembali diuji menggunakan uji Glejser. Deteksi heterokedastisitas dalam uji Glejser menggunakan nilai signifikasi dari setiap variabel independen atau variabel bebas, Apabila nilai signifikansi antara variabel independen dengan absolut residual lebih besar dari (>) 0,05, maka dinyatakan tidak terjadi heterokastisitas. Namun, jika nilai signifikansi antara variabel independen dengan absolute residual lebih kecil $(<)$ dari 0,05 maka dinyatakan terjadi heterokadstisitas. Untuk lebih jelas hasil uji heterokedastisitas dengan uji Glesjer dapat dilihat pada tabel berikut:

Tabel 1.5 Hasil Uji Heterokedastisitas dengan Uji Glesjer

\begin{tabular}{ccc}
\hline & Coefficients $^{\mathrm{a}}$ & \\
\hline Model & $\mathrm{t}$ & $\mathrm{Sig}$ \\
\hline Perhatian Orang Tua (X1) & 1.913 & 0.060 \\
\hline Motivasi Belajar (X2) & 0.679 & 0.499 \\
\hline
\end{tabular}

Sumber : Data diolah tahun 2017

Tabel 1.5 menunjukkan bahwa hasil uji heterokedastisitas dengan menggunakan uji Glesjer dapat diketahui nilai signifikansi untuk variabel perhatian Orang Tua (X1) 0,060, begitu pun dengan Motivasi Belajar (X2) 0,499 yang artinya nilai signifikansinya $>0,05$, maka dapat dinyatakan bahwa tidak terjadi heterokedastisitas dalam model regresi penelitian ini.

\section{PEMBAHASAN}

Perhatian orang tua adalah usaha yang dilakukan orang tua dalam memenuhi kebutuhan anakanya baik kebutuhan fisik, religi, psikis maupun sosial. Oleh karena itu jika orang tua tidak memenuhi semua kebutuhan fisik, psikis,religi maupun sosial dengan sangat baik maka pencapain prestasi belajar 
tidak akan maksimal. Berdasarkan hasil penelitian dapat disimpulkan bahwa terdapat pengaruh positif dan signifikan perhatian orang tua dengan prestasi belajar ekonomi. Dengan demikian, semakin tinggi perhatian orang tua maka akan semakin tinggi pula prestasi belajar peserta didik pada mata pelajaran ekonomi. Hal ini juga berlaku untuk hal sebaliknya yaitu jika perhatian orang tua rendah maka prestasi belajar peserta didik pada mata pelajaran ekonomi juga akan rendah. Hasil analisis dalam penelitian ini dapat dilihat pada table berikut:

\section{Tabel 1.6}

Pengaruh Perhatian Orang Tua Terhadap Prestasi Belajar Peserta Didik Kelas XI SMA Negeri 1 Bontomatene Kabupaten Kepulauan Selayar

\begin{tabular}{llll}
\hline Variabel Independent & B & t-Hitung & Sig \\
\hline Perhatian Orang Tua & 0.259 & 2.913 & 0.005 \\
\hline Konstanta & & 68.553 \\
\hline F Hitung & & 8.486 \\
\hline Sig F & & 0.005 \\
\hline $\mathrm{R}^{2}$ & & 0.103 \\
\hline $\mathrm{N}$ & & 76 \\
\hline
\end{tabular}

Berdasarkan table 1.6, hasil perhitungan dengan menggunakan analisis varian untuk regresi diperoleh $\mathrm{F}$ hitung sebesar $8.484>\mathrm{F}$ tabel 3.97 dengan probabilitas $0.005<0.05$ yang berarti signifikan sehingga $\mathrm{Ho}$ ditolak dan $\mathrm{H}_{\mathrm{a}}$ diterima. Hal ini menunjukkan ada pengaruh perhatian orang tua terhadap prestasi belajar peserta didik pada mata pelajaran ekonomi di kelas XI IPS SMA Negeri 1 Bontomatene.

Koefisien regresi untuk variabel perhatian orang tua sebesar 2,193 bertanda positif yang artinya semakin tinggi perhatian orang tua maka akan semakin tinggi prestasi belajarnya. Hasil analisis perhatian orang tua terhadap prestasi belajar menunjukkan nilai t- Hitung sebesar $2.913>1.666$ dengan nilai signifikan 0,05. Karena nilai signifikan $0,032<0,05$ dapat disimpulkan Ha diterima. Sehingga menunjukan bahwa perhatian orang tua berpengaruh terhadap prestasi belajar

Nilai Koefisien B pada variable perhatian orang tua sebesar 0.259 yang menandakansetiap penambahan tingkat pendapatan orang tua sebesar satu persen (1\%) akan meningkatkan nilai belajar siswa sebesar 0.259 persen. Sementara itu, nilai konstanta pada tabel adalah 68.553 yang berarti bahwa tanpa variabel perhatian orang tua nilai prestasi belajar siswa di kelas XI IPS SMA Negeri 1 Bontomatene Kabupaten Kepulauan Selayar adalah sebesar 68.553 
Berdasarkan uji koefisien determinasi dapat diketahui bahwa besarnya pengaruh perhatian orang tua terhadap prestasi belajar dapat dilihat dari nilai $R$ square, yaitu sebesar 0.103 atau $10.3 \%$. Dengan demikian besarnya pengaruh perhatian orang tua terhadap prestasi belajar peserta didik pada mata pelajaran ekonomi di kelas XI IPS SMA Negeri 1 Bontomatene sebesar $10.3 \%$, sedangkan $89.7 \%$ dipengaruhi oleh faktor-faktor lain yang tidak dikaji dalam penelitian ini.

\section{KESIMPULAN}

Berdasarkan hasil penelitian dan pembahasan penelitian, maka di kemukakan kesimpulan bahwa Perhatian orang tua berpengaruh positif dan signifikan terhadap prestasi belajar peserta didik pada mata pelajaran ekonomi di kelas XI IPS SMA Negeri 1 Bontomatene. esarnya pengaruh perhatian orang tua terhadap prestasi belajar peserta didik pada mata pelajaran ekonomi di kelas XI IPS SMA Negeri 1 Bontomatene sebesar $10.3 \%$, sedangkan $89.7 \%$ dipengaruhi oleh faktor-faktor lain yang tidak dikaji dalam penelitian ini.

\section{DAFTAR PUSTAKA}

Ahmad Susanto, M. P. (2016). Teori belajar dan pembelajaran di sekolah dasar. Kencana.

Akindinova, N., Kuzminov, Y., \& Yasin, E. (2016). Russia's economy: Before the long transition. Voprosy Ekonomiki, 2016(6), 5-35. https://doi.org/10.32609/0042-8736-2016-6-5-35

Gunawan, A. H. (2000). Sosiologi pendidikan. Jakarta: Rineka Cipta.

Jansen, R. S., van Leeuwen, A., Janssen, J., Jak, S., \& Kester, L. (2019). Selfregulated learning partially mediates the effect of self-regulated learning interventions on achievement in higher education: A meta-analysis. Educational Research Review, 28(September), 100292. https://doi.org/10.1016/j.edurev.2019.100292

Park, S. Y., Pan, B., \& Ahn, J. Bin. (2020). Family trip and academic achievement in early childhood. Annals of Tourism Research, 80(June 2018), 102795. https://doi.org/10.1016/j.annals.2019.102795

Partovi, T., \& Razavi, M. R. (2019). The effect of game-based learning on academic achievement motivation of elementary school students. Learning and Motivation, 68(August), 101592. https://doi.org/10.1016/j.lmot.2019.101592

Prasertcharoensuk, T., Somprach, K., \& Ngang, T. K. (2015). Influence of Teacher 
Competency Factors and Students' Life Skills on Learning Achievement. Procedia - Social and Behavioral Sciences, 186, 566-572. https://doi.org/10.1016/j.sbspro.2015.04.021

Sugiyono. 2008. Statistika Untuk Penelitian. Bandung: ALFABETA

Walgito, Bimo. 1994. Pengantar Psikologi Umum. Yogyakarta: Andi Offset

Wulandari, F., Wahyono, H., \& Haryono, A. (2016). Pengaruh Perhatian Orang Tua, Respon Pada Iklan, Intensitas Pergaulan Teman Sebaya, dan Pemahaman Siswa Pada Mata Pelajaran Ekonomi Terhadap Perilaku Konsumsi SIswa Kelas VII SMPN 2 Ngledok Kabupaten Blitar Tahun Ajaran 2015/2016. Jurnal Pendidikan Ekonomi, 9(2), 99-106. 